WHAT EXPENDITURE DOES ANGLOSPHERE FOREIGN BORROWING FUND?

\author{
Anthony J. Makin* \\ Professor of Economics \\ Economics, Griffith Business School \\ Griffith University, Gold Coast 4222 \\ Australia \\ t.makin@griffith.edu.au
}

Paresh Kumar Narayan

Professor of Finance

Financial Econometrics Group, School of Accounting, Economics and Finance, Deakin University, Burwood 3125

Australia

paresh.narayan@deakin.edu.au

\author{
Seema Narayan \\ School of Economics, Marketing, and Finance \\ RMIT University \\ Email: seema.narayan@rmit.edu.au
}

*corresponding author

September 2013 


\title{
WHAT EXPENDITURE DOES ANGLOSPHERE FOREIGN BORROWING FUND?
}

\begin{abstract}
This paper examines the extent to which foreign borrowing funds private investment, consumption and government expenditure in the United States, the United Kingdom, Australia, and New Zealand (the Anglosphere), advanced economies which have been the world's largest international borrowers since 1990. Using a bivariate predictive regression model, we estimate the relative importance of these expenditure aggregates as predictors of their external deficits, and hence foreign borrowing. Overall, based on quarterly macroeconomic data for the period 1990-2011, the evidence suggests that foreign borrowing has not financed higher household consumption in these economies over recent decades, with the possible exception of the United States. While results concerning government spending are mixed due to policy reaction, business cycle and public-private saving offset effects, strong results for private investment augur well for the sustainability of this grouping's foreign borrowing.
\end{abstract}

JEL: F32, F41, F47

Keywords: Expenditure; Current Account Deficits; Foreign Borrowing; Anglosphere Economies. 


\section{Introduction}

Since the early 1990s, the most persistent current account deficits in the world economy have been those of the United States, the United Kingdom, Australia, and New Zealand (hereafter the 'Anglosphere'). By comparison, East Asia, most notably China and Japan, and the oil exporting nations, posted current account surpluses over much of this time. With a current account deficit that has reached over six per cent of its GDP at times, the United States has been the world's largest international borrower, regularly attracting over half of traded global saving. The United Kingdom has borrowed substantially from abroad as well for over two decades, while Australia and New Zealand have been reliant on foreign funding for much of their history. Canada, another candidate member of this group, also now posts significant current account deficits, though is here excluded since this has become evident only recently.

\section{INSERT FIGURE 1}

The nexus between national expenditure and current account deficits has long been established in the international macroeconomics literature. For instance, Alexander (1952) first recognized that current account deficits reflected the difference between economy's total expenditure, or absorption, and its national output. Moreover, the still popular Mundell (1963) - Fleming (1962) model suggests autonomous spending shocks

are ineffective in raising national income under a floating exchange rate. Instead, spending shocks 'crowd out' net exports, thereby raising the current account deficit. 
External deficits and the associated foreign borrowing can, in theory, benefit economies by allowing internationally traded saving to move where it earns its highest rate of return. Viewed in this light, external imbalances reflect national differences in saving habits and investment opportunities, rather than differences in nations' trade competitiveness, and can raise living standards in lender and borrower economies alike. If private investment, which adds to the economy's capital stock, is the key determinant of international borrowing, external deficits can be viewed benignly, consistent with intertemporal models of the current account (see for instance Sachs 1981, Frenkel and Razin 1987, Obstfeld and Rogoff 1996). In the national balance sheet, higher foreign debt incurred this way is matched by income generating assets and improves national income as long as the rate of return on the foreign funded assets exceeds the cost of foreign capital.

Under certain conditions it may be acceptable to finance consumption by borrowing from abroad, for instance by smoothing short term consumption when output is below its long term value, as originally proposed by Sheffrin and Woo (1990). On the other hand, if foreign borrowing persistently finances additional private consumption, or unproductive government spending, current account deficits can become a concern from a policy perspective. Under these circumstances, where consumption and current account deficits are related over the longer term, economies are effectively 'living beyond their means' as rising external liabilities are not being matched in the national balance sheet by income generating assets. Public sector borrowing abroad can lead to unsustainably high external debt levels, as suggested by the experience of Greece, Italy, Portugal, Spain, Ireland, all of which emerged as significant foreign borrowers in recent years, culminating in the 2011-12 sovereign debt crisis in the eurozone. 
The literature on the "twin deficits" hypothesis is relevant in this context. Earlier empirical studies of this hypothesis for the United States and many other economies, have yielded mixed results, showing that current account deteriorations have reached as much as forty per cent of any shift in fiscal imbalances (see, for instance, Chinn and Prasad 2003, Corsetti and Müller 2006, Dibooglu 1997, Kraay and Ventura 2000, Nason and Rogers 2002 and Normandin 1999 and Nason and Rogers 2002). In contrast, Kim and Roubini (2008) found that for the United States the current account balance actually improved when the fiscal balance deteriorated. However, many previous studies of the linkages between fiscal activity and current account imbalances have focussed on federal government spending or federal budget imbalances, not spending or fiscal imbalances for all levels of government, as recorded on the national accounts basis adopted in this paper.

Moreover, in examining the twin deficits, many have not distinguished between budget deficits that arise from higher government spending and those arising from lower revenues. Yet, a rise in aggregate public spending, the public account variable we focus on, could conceivably contribute more to external deficits than revenue changes due to differences in the degree of offsetting private saving behavior. For example, the life cycle (Modigliani 1986) and permanent income (Friedman 1957) theories of consumption imply that household consumption will not rise proportionately with temporary, tax related, income variation if households treat the taxes as transitory rather than permanent (Taylor 2009). Not normally considered in the context of external account determination, this offset between public saving and private saving has also been tested previously as a manifestation of Ricardian equivalence (Barro 1974, Bernheim 1987, Seater 1993, 
Ricciuti 2003). Using World Bank data for 150 countries, Loayaza, Schmidt-Hebbel and Serven (2000) for instance have found this offset close to 0.7.

The main aim of this paper is to address the nexus between different types of aggregate expenditure - private investment, private consumption and government spending as recorded on a national accounts basis - and the extent to which they are foreign financed in Anglosphere economies. To do this, we first employ a simple extended loanable funds framework to convey how expenditure types in principle affect the current account deficit and foreign borrowing (terms used synonymously in what follows). We then focus on the experiences of each of the Anglosphere economies since 1990, empirically identifying which types of spending foreign borrowing has funded. We discover that investment predicts current account deficits and hence foreign borrowing in all countries in our sample, while government spending predicts current account deficits for the United States, the United Kingdom, and Australia. When we use consumption as a predictor of current account deficits, predictability is only found in the case of the United States.

The remainder of the paper proceeds as follows. The next section outlines conceptual links between various expenditure types and foreign borrowing. We then describe the data and the econometric methods used before reporting our empirical results. A robustness test is undertaken in the penultimate section. The concluding section summarizes the key findings and draws implications for interpreting the sustainability of the external imbalances of Anglosphere economies. 


\section{Expenditure, the Current Account and Foreign Borrowing}

From the familiar national accounting identity

$$
\operatorname{cad}=(C+I+G)-Y_{n}=-\left(Y_{n}-C\right)+I+G
$$

where, cad, the current account deficit, is net imports plus net income paid abroad, $C$ is private consumption, $I$ is private investment, $G$ is government spending, and $Y_{n}$ is national production or income, net of income paid abroad. Adding and subtracting tax revenue, $T$, to relation (1) yields

$$
\operatorname{cad}=I-\left(Y_{n}-T-C\right)+(G-T)=I-\left(S_{p}+S_{g}\right)
$$

where $S_{p}$ is private saving and $S_{g}$ is public saving or the so-called operational budget deficit.

\subsection{An Extended Loanable Funds Framework}

Relation (2) underpins the international loanable funds framework in Figure 2 linking domestic saving, investment and international borrowing, variables which are governed by the following relations ${ }^{1}$

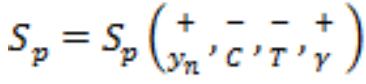

$$
\begin{aligned}
& I=I\left(\bar{r}^{\prime},+\right) \\
& c a d=L^{*} \\
& r=r\left(\underset{r^{*},}{\stackrel{+}{*} L^{*}}\right)
\end{aligned}
$$

\footnotetext{
${ }^{1}$ We abstract from postulating microeconomic foundations which are deemed non-essential for the analysis to follow based on these standard summary form relations.
} 
where $\gamma$ is wealth, $r^{*}$ is the foreign real interest rate, $L^{*}$ is foreign lending. Signs above the variables signify those of the first partial derivatives.

National saving and investment are independently determined in financially open economies. The vertical schedule in Figure 2 depicts domestic saving, consistent with the standard assumption that consumption, and hence private saving, is unresponsive to the real interest rate in the short run, though relaxing this assumption would have no effect on the results to follow. Meanwhile, $I$ is inversely related to the interest rate, as proposed by orthodox investment theory (see Romer 2012). Although some macroeconomics texts relate domestic saving, investment and external imbalances to real interest rates in an ostensibly similar way, this extension differs by introducing a rising supply price of foreign lending, as shown in the right panel of the figure. This illustrates that any additional domestic expenditure contributing to an economy's ex ante current account deficit is only funded ex post to the extent of the lending willingly provided from abroad.

\section{INSERT FIGURE 2}

International macroeconomic models usually unrealistically assume that economies have unlimited access to foreign saving at 'the world interest rate.' However, if economies are large, accessing funds from abroad will endogenously push up the real interest rate. On the other hand, if relatively small economies borrow from abroad, foreign lenders are likely to demand an interest risk premium, increasing in the level of their foreign 
indebtedness, which raises their real interest rates. Hence, for large economies (United States, United Kingdom) or small economies (Australia, New Zealand) the supply price of foreign funds should increase as their external deficits and foreign borrowing rise, as shown by the upward sloping $L^{*}$ schedule in Figure 2. A creditworthiness downgrade would steepen the slope of this schedule.

\subsection{Investment, Consumption and Government Spending Shocks}

In Figure 1 it is assumed in initial equilibrium that $S=I$, so $c a d=0$. An increase in $I$, other things equal, increases $c a d$ and $r$, as mapped in the right side panel, where the $C D$ schedules reflect the ex ante borrowing requirement in equilibrium domestic $r-\mathrm{cad}$ space and the $L^{*}$ schedule shows a rising cost of foreign funds schedule. Hence this approach suggests $I$ should be a significant $c a d$ determinant. Moreover, since $I$ is a procyclical macroeconomic variable, a rise in $I / G D P$ should increase cad/GDP.

Next consider the effects of household consumption shocks. Higher consumption, reduces saving, other things equal, which also leads to an external deficit and higher interest rates, as depicted in Figure 3. Hence, positive $C$ shocks imply that a rise in $C / G D P$ also potentially contributes to a rise in $c a d / G D P$.

\section{INSERT FIGURE 3}

Lastly, consider the relationship between government spending and foreign borrowing. To the extent that higher government spending reduces saving it has the same effect as a rise in household consumption. However, several factors complicate the relationship 
between government spending and the current account deficit, particularly when these variables are expressed as a proportion of GDP. First, there is likely to be some offset in private saving due to Ricardian effects that shift the saving schedule back, minimizing the impact of increased government spending on the foreign borrowing requirement. Second, government spending is often used as a countercyclical instrument operating through automatic stabilizers as well as discretionary fiscal measures. This tends to increase (decrease) public spending during cyclical downturns (upswings).

Relatedly, unlike the $C / G D P$ and $I / G D P$ ratios, the $G / G D P$ ratio may move inversely with the cad/GDP ratio due to business cycle related measurement effects. For instance, if there is an investment boom, such as that which occurred in the Anglosphere as a result of the positive technology shock of the late 1990s, the cad/GDP ratio would tend to rise, yet the $G / G D P$ ratio would simultaneously fall if government spending rose more slowly than output.

Third, due to policy concerns about the perceived risks of unsustainable external imbalances, governments may react directly to growing external deficits, irrespective of the business cycle, by cutting public spending. For all of these reasons, the nexus between $G / G D P$ and $c a d / G D P$ is more ambiguous in theory than between the $I / G D P$ and $C / G D P$ and $c a d / G D P$, potentially yielding a negative relationship. This is reflected 
in the empirical evidence to date on the relationship between fiscal shocks and the current account imbalance which remains mixed. ${ }^{2}$

In sum, this loanable funds approach explains how consumption, investment and government spending are linked to the current account and foreign borrowing and provides a basis for our testable hypotheses. If private investment is a significant determinant of current account deficits, the foreign borrowing undertaken to finance it can be considered benign and of the nature conveyed in standard intertemporal models. On the other hand, if consumption, or government spending, positively influence external deficits, this is cause for policy concern; questions arise about the sustainability of the foreign debt incurred as it is not matched by income generating real assets in the national balance sheet.

In particular, to test this approach we apply a current account predictive regression framework, where: (a) we first examine whether investment, consumption and government spending predict current account deficits, and (b) then we test using an outof-sample forecasting exercise, whether our proposed cad predictive regression model outperforms a constant current account model.

\footnotetext{
2 For instance, previous VAR studies by Monacelli and Perotti (2010) and Cardi and Muller (2011) find the US current account deficit worsens following fiscal shocks, whereas Kim and Roubini (2008) and Muller (2008) find it improves.
} 


\section{Econometric Approach}

\subsection{Basic framework}

Our bivariate predictive regression model takes the following:

$$
C A D_{t}=\beta_{0}+\beta_{1} P_{t-1}+\varepsilon_{t}
$$

Here $C A D$ is the current account deficit as a percentage of GDP and $P$ represents each of our three predictor variables, namely investment as a percentage of GDP, government spending as a percentage of GDP, and consumption as a percentage of GDP. The error term is characterized by a zero mean and variance $\sigma^{2}$.

The predictor variable is typically modeled as follows:

$$
P_{t}=\mu(1-\rho)+\rho P_{t-1}+\varepsilon_{t}
$$

This framework allows us to model the persistency and endogeneity of the predictor variable. When predictors are highly persistent and their innovations correlated with innovations of the regressand, the result is a small-sample bias in the conventional ordinary least squares estimator (see Stambaugh, 1999).

The null hypothesis of no predictability is $H_{0}: \beta=0$. It is reasonable to assume at least for a start that, $\gamma$, the correlation between $\epsilon_{t}$ and $\varepsilon_{t}$ is statistically significant. We, therefore, have the following relationship between the error terms:

$$
\epsilon_{t}=\gamma \varepsilon_{t}+\eta_{t}
$$

Where $\varepsilon_{t}$ and $\eta_{t}$ are iid and symmetric with mean zero, and finite fourth-order moments. The variances of $\varepsilon_{t}$ and $\eta_{t}$ are denoted by $\sigma_{s}^{2}$ and $\sigma_{\eta}^{2}$, respectively. 


\subsection{The Lewellen estimator}

Lewellen (2004) proposes a bias-adjusted ordinary least squares (OLS) estimator, which is motivated by the fact that if the contemporaneous correlation between innovations is negative and the estimate of $\rho$ is expected to be lower than one, the estimate of $\rho$ enters positively in the Lewellen estimator as follows:

$$
\hat{\beta}_{1}=\hat{\beta}_{1}^{O L S}+\frac{\operatorname{cov}\left(\epsilon_{t}, \varepsilon_{t}\right)}{\operatorname{var}\left(\varepsilon_{t}\right)} \times[0.9999-\hat{\rho}]
$$

It follows that with the Lewellen estimator, the higher the estimate of $\rho$ (effectively a random walk process for the predictor variable), the more $\beta$ approaches an OLS $\beta$.

\subsection{The Westerlund and Narayan estimator}

Westerlund and Narayan $(2011,2012)$ propose a generalized least squares (GLS) estimator of $\beta$, which is based on an augmented version of Equation (7), and has the following form:

$$
C A D_{t}=\alpha-\gamma \mu(1-\rho)+\beta^{a d j} P_{t-1}+\gamma \Delta P_{t}+\epsilon_{t}
$$

where $\beta^{a d j}=\beta-\gamma(\rho-1)$ can be interpreted as the limit of the bias-adjusted OLS estimator of Lewellen (2004). Westerlund and Narayan (2011) assume that $\rho=1+\frac{c}{T}$, where $c \leq 0$ is a drift parameter that measures the degree of persistency of the predictor variable. The implication is that if $c=0$, then the predictor variable has an exact unit root, whereas, if $c<0$ then it is locally stationary in the sense that $\rho$ approaches one from below as $T$ increases. 
Westerlund and Narayan (2012) show how to model heteroskedasticity by using the following variance equation for $\eta_{t}$ :

$$
\operatorname{var}\left(\eta_{t} \mid I_{t-1}\right)=\sigma_{\eta t}^{2}=\lambda_{0}+\sum_{j=1}^{q} \lambda_{j} \eta_{t-j}^{2}
$$

Where $I_{t}$ is the information available at time $t$. In order to ensure that $\sigma_{\eta}^{2}$ is positive, Westerlund and Narayan (2012) assume that $\lambda_{0}>0, \lambda_{1}, \ldots, \lambda_{q} \geq 0$ and $\sum_{j=1}^{q} \lambda_{j}<1$. They then also apply a simple ARCH model assumption to $\operatorname{var}\left(\varepsilon_{t} \mid I_{t-1}\right)=\sigma_{s t}^{2}$. The Westerlund and Narayan (2012) GLS-based t-statistic for testing $\beta_{1}=0$ takes the following form:

$$
t_{G L S}=\frac{\hat{\beta}_{1, G L S}}{1 / \sqrt{\sum_{t=2}^{T} \omega_{t}^{2}\left(P_{t-1}^{d}\right)^{2}}}
$$

Here, $\omega_{t}=1 / \sigma_{C A D_{0} t}$ is the GLS weight, $\hat{\beta}_{1, G L S}$ is the GLS estimator of $\beta_{1}$ from Equation (7), and $P_{t}^{d}=P_{t}-\sum_{s=2}^{T} P_{s} / T$.

\section{Results}

We use quarterly data on current account deficit as a percentage of GDP (CAD), government spending as a percentage of GDP (G), investment as a percentage of GDP (I), and consumption expenditure as a percentage of GDP (C). All data was downloaded from OECD and IMF databases for the United States, the United Kingdom, Australia, and New Zealand. The national accounts data expressed in respective domestic currencies were sourced online from the International Monetary Fund's International Financial Statistics. As current account deficits in the IMF database are published in United States dollars only, these data expressed in domestic currency terms were sourced 
online from the Datastream OECD database. All data series are quarterly and span the period 1990-2011.

Since the objective of this study is to examine whether government spending, consumption expenditure and investment predict current account deficits, it is important to gauge the basic relationship between deficits and their predictors. In Figure 4, we plot unconditional time-varying correlation between CAD-G, CAD-I and CAD-C. We estimate time-varying correlations through using a 5-year rolling window. In this way, while we lose the first five years of the sample period we end up with a time series of correlations between $\mathrm{CAD}$ and their predictors. These correlations for each of the four countries are plotted in Figure 4.

For all countries, CAD is most highly correlated with investment; the correlations are in the $[0.26,0.61]$ range, and as the plots suggest they vary with time. In some time periods they are high relative to others and also reflect cyclical influences. For instance, there was a decline in the importance of investment for all four countries, most notably for the United Kingdom, Australia and New Zealand, due to the global uncertainty that prevailed in the lead up to the North Atlantic banking crisis that climaxed in September 2008 severely disrupting financial markets worldwide until 2010. Except for New Zealand where the weakest correlation is found between CAD and government spending, for the rest of the countries the weakest correlation is found between CAD and consumption expenditure. Again, the correlations between CAD and government spending and between $\mathrm{CAD}$ and consumption expenditure are time-varying. The key implication here is that different predictors have different magnitudes of correlation with deficits and these 
correlations are time-varying, high during some phases and low during other phases. These trends demand two specific questions: (1) Do these predictors actually predict deficits?; and (2) where there is predictability is the model stable?

\section{INSERT FIGURE 4}

In Table 1 we report results from a test of unit roots. Our approach is as follows. We use the Dickey and Fuller (1979) test, which allows one to control for serial correlation by including lags of the first difference of the variables on the right-hand side of the test regression. We set the maximum lag length to eight and then use the Schwarz Information Criterion to obtain the optimal lag length. The null hypothesis is that there is a unit root. The results from the model with an intercept for both levels and the first difference of the four variables are presented; in particular, we report the test statistic and the associated p-value needed to take a decision on the null hypothesis.

For the CAD variable, we reject the null at the 5\% level for Australia and New Zealand, and at the $1 \%$ level for the United Kingdom. For the United States, the null is not rejected. Hence, while CAD is stationary for Australia, New Zealand, and the United Kingdom, for the United States, it is non-stationary. The first difference of the CAD turns out to be highly stationary as the null is rejected for all countries at the $1 \%$ level. Next we read the results for government spending. We find that the null is not rejected for any of the four countries, suggesting that government spending is non-stationary. Meanwhile, we notice that the first difference of government spending is stationary for all countries. 
Turning to investment, we reject the null only for the United Kingdom (at the $10 \%$ level). We, therefore, conclude that investment is non-stationary for all countries except for the United Kingdom. Finally, we consider consumption expenditure as a percentage of GDP and find that the null is rejected at the $10 \%$ for Australia and at the $5 \%$ level for New Zealand. For the United Kingdom and the United States, consumption is found to be nonstationary in levels but stationary in first difference form. This suggests that consumption for these two countries contains a unit root.

\section{INSERT TABLE 1}

Our unit root test, therefore, suggests that most of the predictor variables are highly persistent. We now turn to the issue of endogeneity of the predictor variables. The correlation coefficients between the errors based on Equation (9) and its t-statistic are reported in Table 2. In column 2, we report results when government spending is the predictor variable, in column 3 we report results when investment is the predictor variable, and the final column contains results for the consumption predictor variable. When government spending is the predictor variable, only for the United Kingdom and the United States there is evidence of endogeneity. When investment is the predictor variable only for New Zealand there is evidence that it is endogenous.

Finally, when consumption is the predictor variable endogeneity exists only for the United States. The main implication here is that in estimating predictive regression models, the salient features of our data, namely persistency and endogeneity of the 
predictor variables, need to be explicitly accounted for. The two models (Lewellen, 2004; Westerlund and Narayan, 2011, 2012) we use, account for these features of the data.

\section{INSERT TABLE 2}

The test results from the Lewellen and Westerlund and Narayan estimators are reported in Table 3. Panel A contains results when government spending is the predictor variable, Panel B contains results when investment is the predictor variable, and Panel C contains results when consumption is the predictor variable. Beginning with results for government spending, we find that the null hypothesis of no predictability is rejected for United States, the United Kingdom, and Australia. Only for New Zealand we find no

evidence that government spending predicts CAD. The results from the Lewellen estimator are consistent with those obtained from the Westerlund and Narayan estimator. Therefore, our finding that government spending predicts current account deficits in Australia, the United Kingdom, and the United States is robust.

\section{INSERT TABLE 3}

When investment is the predictor variable, we notice that for all four countries it predicts current account deficits. The null of no predictability is very strongly rejected, at the $1 \%$ level, for all countries. Moreover, we notice that both estimators provide consistent evidence of predictability. When we consider consumption spending, we find that the null of no predictability cannot be rejected for Australia, New Zealand, and the United 
Kingdom. However, the null is rejected for the USA at the $10 \%$ level. We, therefore, conclude that consumption predicts the current account deficit of the United States only and not for the other three countries in our sample.

On the whole, when we compare evidence of the predictability of the current account deficit, we notice that consumption is the only predictor which predicts current account deficits for all countries. Government spending is the second most popular predictor; except for New Zealand, it predicts current account deficits for all countries. Finally, we observe that consumption has the weakest effect on current account predictability; it only predicts the CAD of the United States.

\subsection{Out-of-sample forecasting performance}

It is perhaps debatable whether in-sample tests should be preferred to out-of-sample tests for predictability. Inoue and Kilian (2004: 372-372) argue that in-sample tests tend to reject the null hypothesis of no predictability more often than out-of-sample tests when applied to the same data set. Yet, they contend that in-sample predictability tests should be preferred to out-of-sample tests. Rapach and Wohar (2006) and Foster et al. (1997), on

the other hand, argue that out-of-sample tests provide a measure of protection against data mining, as statistical models are tested using out-of-sample observations that are not part of the initial model estimation. To avoid being caught in this debate, the aim of this section is to undertake an out-of-sample test for the predictability of the current account deficit. 
Our approach is as follows. For each of the four countries, we divide the total sample of observations $(T)$ into an in-sample component $\left(T_{1}\right)$ and an out-of-sample component $\left(T_{2}\right)$. Because we have at most $T=88$, we follow Rapach and Wohar (2006) and Westerlund and Narayan (2012) and consider 50\% of $T$ as in-sample and the other 50\% as out-of-sample. We use a recursive procedure to generate out-of-sample forecasts. We compute out-of-sample forecasts based on Equation (7) - we call this the unrestricted model. We then restrict Equation (7) by setting $\beta_{1}=0$, thereby generating forecasts from a restricted model:

$$
C A D_{t+1}=\beta_{0}+\varepsilon_{t+1}, \quad \varepsilon_{t+1} \sim N\left(0, \sigma^{2}\right)
$$

We use GLS to obtain the in-sample estimates of the parameters of Equation (7), which are then used to forecast out-of-sample. This step is repeated for the restricted model. An excellent discussion on the methodology can be found in Rapach and Weber (2004). It follows that we have on hand two models: the unrestricted model, which is essentially our government spending, investment, and consumption predictive regression models of current account deficits and the restricted model of constant current account deficits. We use a range of commonly used metrics for comparing forecasts from the two models.

First, we consider the ratio of the root mean squared forecast error (RMSFE) for the unrestricted model forecasts to the RMSFE for the restricted model forecasts. If this statistic is less than one it suggests that our proposed current account predictive regression model with government spending, investment, and consumption as predictors outperform the constant current account model. 
We also use the MSE-F test, which examines the null hypothesis that restricted and unrestricted models have equal forecasting ability. The null is tested against the one-sided (upper-tail) alternative hypothesis that the mean squared forecasting error (MSFE) for the unrestricted model forecasts is less than the MSFE for the restricted model forecasts. When the MSE-F test is statistically significant it implies that the unrestricted model forecasts are statistically better those obtained from the restricted model.

We also use the Clark and McCracken (2001) forecast encompassing test, commonly referred to as the ECN-NEW test. The null hypothesis is that the restricted model forecasts encompass the unrestricted model forecasts. The one-sided upper-tail alternative hypothesis is that the restricted model forecasts do not encompass the unrestricted model forecasts. If we reject the null, we conclude that the predictors contain information that can be used to predict current account deficits.

The results, reported in Table 4, are organized as follows. For each of the three predictors, the three out-of-sample test results are reported. Reading the results first when investment in the predictor variable, we note the following. First, except for the United Kingdom, the relative RMSFE statistics are less than one and statistically significant, implying that the RMSFE from the unrestricted model is less than those from the restricted model. This suggests that investment is a better predictor of current account deficits than a constant current account model. Second, when we consider government spending as the predictor variable the relative RMSFE statistics are less than one for the United Kingdom and Australia, suggesting that for these two countries government 
spending is a better predictor of current account than a constant current account model.

For New Zealand and the United States, the statistic is statistically insignificant.

\section{INSERT TABLE 4}

Third, when we consider the MSE-F, which examines the null hypothesis that restricted and unrestricted models have equal forecasting ability, we find that:

1. When investment is the predictor variable, the $M S E-F$ statistic is statistically insignificant for the United Kingdom. It is, however, statistically significant for NZ, the United States, and Australia, suggesting that unrestricted model forecasts are statistically better those obtained from the restricted model.

2. When government spending is the predictor variable, the $M S E-F$ statistic is statistically significant only for the United Kingdom and Australia, suggesting that the mean squared forecast error from the unrestricted model is less than those from the restricted model.

3. When consumption is the predictor variable, only for the United States the MSE$F$ is statistically significant.

Finally, when we consider evidence from the ENC-NEW test, the evidence corroborates those obtained from the RMSFE test.

Taken on the whole, these out-of-sample results lead us to the following conclusions. First, consistent with our in-sample predictability test results, we find that in out-ofsample tests, investment predicts current account deficits for more countries compared to the government spending and consumption predictors. Second, in-sample tests reveal 
stronger evidence of predictability. In in-sample tests, we discovered that the investment predictor predicted current account deficits for all countries.

However, with out-of-sample tests, there was no evidence that investment predicted current account deficits for the United Kingdom. With the government spending predictor, in-sample tests suggested no predictability for New Zealand, while the out-ofsample tests suggested no predictability for New Zealand and the United States. With the consumption predictor, both in-sample and out-of-sample tests revealed predictability, but only for the United States. On the whole then, out-of-sample tests provide relatively less evidence of predictability compared to in-sample tests.

\section{Robustness test}

One referee of this journal suggested that we consider two additional sets of results to ascertain the robustness of our findings. These suggestions are: (a) test whether using multiple predictors changes the conclusions; and (b) test whether the global financial crisis impacted the predictive ability of government spending, investment, and consumption. We agree with these suggestions and begin by first testing whether multiple predictors - that is, pairs of two predictors predict current account deficits and beat the constant current account deficits model. To achieve this goal we simply extend the Westerlund and Narayan (2012) bivariate predictive regression model to a multivariate one. This amounts to estimating for each country three predictive regression models: one in which government spending and consumption are predictors, the other in which 
government spending and investment are predictors, and the final one in which consumption and investment are predictors.

The results are reported in Table 5. In bivariate models, we found that government spending negatively predicted current account deficits for Australia and the United States and positively for the United Kingdom while no evidence of predictability was found for New Zealand. When government spending predictor is used together with the consumption predictor (Panel A) and investment predictor (Panel B), the results are consistent with those from bivariate models. With regard to the investment predictor now: when it is used together with the government spending predictor (Panel B) and with the consumption predictor (Panel $\mathrm{C}$ ), in both models investment consistently predicts current account deficits for all four countries. These results are again consistent with those obtained from bivariate current account models where investment was used as a predictor.

Finally, we read the results from using consumption predictor, with government spending in Panel A and with investment in Panel C. Recall that with bivariate model, we found that only for the United States consumption predicted current account deficits. When consumption is used together with government spending as predictors, the result that consumption only predicts current account deficits of the United States holds. However, when consumption is modelled together with investment as predictors, we find that it predicts current account deficits for United States and Australia. 
In Australia's case, due to wide ranging structural reforms, there were strong productivity gains over this time relative to other OECD economies. This raised the level of income and wealth considerably, thereby bolstering both private consumption and investment expenditures. And it is this that is actually reflected in the strong evidence of CAD predictability driven by consumption and investment expenditures for Australia. On the whole our results from bivariate predictive regression models are consistent with those from multivariate predictive regression models with the exception of consumption in the case of Australia.

\section{INSERT TABLE 5}

We also estimate the out-of-sample relative Theil U (RTU) statistic which is simply the ratio of the Theil $\mathrm{U}$ statistic from our proposed predictive regression model to the Theil $\mathrm{U}$ from a constant current account deficits model (benchmark model). The estimation is based on a 50\% in-sample period. The results are reported in Panel D of Table 5. When RTU $<1$ it implies that our proposed predictive regression model outperforms the benchmark model.

When using both government spending and consumption predictors we find that except for New Zealand the predictive regression model outperforms the constant model for all the other three countries. When government spending and investment are used as predictors the proposed model outperforms the constant model for three of the four countries. And, finally, when using the investment and consumption predictors we find 
that except for the United Kingdom there is strong support in favour of our proposed predictive regression model.

As with bivariate models, the main outcome from multivariate predictive regression models is that there is greater evidence of in-sample predictability compared to out-ofsample predictability.

To conclude this section, we consider whether the results are affected by the 2007 global financial crisis. To test this, we simply consider a sample period excluding the crisis. In other words, we consider a sample period 1990Q1 to 2006Q4. The results are reported in Table 6. We find that the global financial crisis had not impacted our results on predictability (or lack of it) for most countries; Australia and New Zealand are the only exceptions with respect to the consumption and government spending predictors, respectively. The main results hold though.

First, investment which had predicted current account deficits for all four countries over the 1990Q1 to 2011Q4 also predicts deficits in all four countries over the pre-crisis period (1990Q1 to 2006Q4). Second, over the 1990Q1 to 2011Q4 period consumption was the weakest predictor, only predicting deficits of the USA. Over the pre-crisis period in addition to predicting deficits of the USA, consumption predicts deficits of Australia.

Finally, with regard to the government spending predictor, evidence of predictability for Australia weakens, reflecting the fact there was quite minimal variation in government 
spending as a proportion of GDP during the pre-crisis period. Yet for New Zealand, whose government spending as a proportion of GDP pre-crisis varied considerably more, it improves when modelled together with investment but not when modelled together with consumption. Therefore, that government spending predicts deficits for New Zealand in the pre-crisis period is not robust to different model specifications.

\section{INSERT TABLE 6}

A final point we make is about parameter stability. One of the key implications of our analysis of time-varying unconditional correlations was not only that correlations between $\mathrm{CAD}$ and its predictors were strongly time-dependent, correlations were significantly high in some phases while low during other phases. This has implications for the stability of the predictive regression models. We test for parameter instability using the CUSUM test. We find that parameters are generally unstable when we use data for the period 1990-2012; however, when we exclude the global financial crisis period and consider models over the period 1990-2006, the models become relatively more stable. Due to space constraints, as these CUSUM plots span over four pages, we do not plot the CUSUM test results here but they are available upon request. In this section we showed that our results on the predictability of the CAD are generally robust and do not change significantly when we exclude the global financial crisis period. This means that the evidence of parameter stability has not changed the results on predictability of CAD. This is not to say that parameter stability is not important; it is, therefore, future studies should consider estimating our proposed models using a structural break predictive regression framework, such as the one recently proposed by Narayan et al. (2013). 


\section{Conclusion}

This paper presents a new way of assessing whether the current account deficits of Anglosphere economies are consistent with the necessary macroeconomic conditions for sustainable foreign borrowing. Based on international flow of funds precepts, it proposes a current account model in which private investment, household consumption, and government spending appear as predictors. By empirically testing the current account predictive regression model using quarterly data for the period 1990 to 2011, we discover that investment predicts current account deficits and hence foreign borrowing in all countries in our sample, while government spending predicts current account deficits for the United States, the United Kingdom, and Australia.

When we use consumption as a predictor of current account deficits, predictability is only found in the case of the United States. This implies that consumption smoothing has not been the predominant driver of external imbalances in this grouping. The robustness of these results are demonstrated through using a multivariate predictive regression model for each country. The results that investment predicts current account deficits for all countries and consumption only predicts deficits of the United States generally hold, notwithstanding that at times during the sample period, such as the lead up to the Global Financial Crisis and its aftermath, the degree of correlation varied; see Figure 4 (Panel A). 
Using an out-of-sample forecasting exercise, we show that our proposed current account models out-perform a simple constant current account model for most of the countries in our sample. This is true regardless of whether on uses a bivariate or a multivariate predictive regression model. On the whole, both in-sample and out-of-sample tests provide strong evidence that government spending and investments are strong predictors of current account deficits. Although we note, as is common in the predictability literature, that in-sample evidence of predictability is stronger than those obtained from out-of-sample tests.

Overall, the evidence suggests that foreign borrowing has not been financing higher household consumption in the Anglosphere over recent decades, with the possible exception of the United States. Hence, on that basis these economies have, by and large, been 'living within their means.' Moreover, the strength of the relationship between private investment and foreign borrowing for all four economies underpins the sustainability of their foreign borrowing.

However, before drawing conclusions about how welfare enhancing foreign borrowing has been for each country it would be necessary to assess the productivity of the foreignfinanced capital that accumulated over this time. This would include, for instance, the extent to which foreign borrowing contributed to residential investment and the possibility that it facilitated housing bubbles in these economies. 


\section{REFERENCES}

Alexander, S. (1952) "Effects of a Devaluation on a Trade Balance", IMF Staff Papers, 2, 263-78.

Barro, R. (1974) “Are Government Bonds Net Wealth?” Journal of Political Economy, $81,1095-1117$.

Bernheim, D. (1987) "Ricardian Equivalence: An Evaluation of Theory and Evidence" in S. Fischer (ed.) NBER Macroeconomics Annual 1987, Cambridge, MIT Press, Massachusetts.

Cardi, O. and Muller, G. (2011) "Habit Formation and Fiscal Transmission in Open Economies" Journal of International Economics 85, 256-267.

Chinn, M. and Prasad, E. (2003) "Medium term determinants of current accounts in industrial and developing countries: an empirical exploration" Journal of International Economics 59, 47-76.

Clark, T.E., and McCracken, M.W., (2001) Tests of equal forecast accuracy and forecast encompassing for nested models, Journal of Econometrics, 105, 85-110.

Corsetti, G and Muller, G. (2006) "Twin deficits: squaring theory, evidence and common sense" Economic Policy, 48, 597-638.

Dibooglu, S. (1997) "Accounting for US current account deficits: an empitical investigation" Applied Economics, 29, 787-793.

Dickey, D.A., and Fuller, W.A., (1979) Distribution of the estimators for autoregressive time series with a unit root, Journal of the American Statistical Association, 74, 427-431. 
Engle, R.F., and Granger, C.W.J., (1987) Cointegration and error correction: representation, estimation and testing, Econometrica, 55, pp. 251-276.

Foster, F.D., Smith, T., and Whaley, R.E., (1997) Assessing goodness-of-fit of asset pricing models: the distribution of the maximal $R^{2}$, Journal of Finance, 53, 591-607.

Frenkel, J., \& Razin, A. Fiscal Policies and the World Economy, $3^{\text {rd }}$ edition, Cambridge, Massachusetts: MIT Press, 1996.

Fleming, J. (1962) "Domestic Financial Policy Under Fixed and Floating Exchange Rates." IMF Staff Papers, 9(3): 369-79.

Friedman, M. (1957) A Theory of the Consumption Function, Princeton University Press, New Jersey.

Gregory, A. and Hansen, B. (1996) Residual based tests for cointegration in models with regime shifts, Journal of Econometrics, 70, 99-126.

Inoue, A., and Kilian, L., (2004) In-sample or out-of-sample tests of predictability: Which one should we use? Econometric Reviews, 23, 371-402.

Kim, S. and Roubini, N. (2008) "Twin deficit or twin divergence? Fiscal policy, current account, and real exchange rate in the US" Journal of International Economics, 74, 362383.

Kraay, A. and Ventura, J. (2000) "Current accounts in debtor and creditor countries" Quarterly Journal of Economics 115, 1137-1166. 
Lewellen, J., (2004) Predicting returns with financial ratios, Journal of Financial Economics, 74, 209-235.

Loayza, N. Schmidt-Hebbel, K. and Serva, L. (2000) "What Drives Private Saving Across the World?" Review of Economics and Statistics 82, 165-181.

McCracken, M. W., (2007) Asymptotics for out-of-sample tests of Granger causality, Journal of Econometrics, 140, 719-752.

Masson, P. Bayoumi, T. Samiei, H. (1998) "International evidence on the determinants of private saving” World Bank Economic Review 12: 483 - 501.

Modigliani, F. (1986) "Life Cycle, Individual Thrift, and the Wealth of Nations" American Economic Review 76, June, 297-313.

Monacelli, T. and Perotti, R. (2010) "Fiscal Policy, the Real Exchange Rate and Traded Goods" Economic Journal, 120, 437-461.

Muller, G. (2008) "Understanding the Dynamic Effects of Government Spending on Foreign Trade" Journal of International Money and Finance 27(3), 345-371.

Mundell, R. (1963) "Capital Mobility and Stabilization Policy Under Fixed and Flexible Exchange Rates." Canadian Journal of Economics and Political Science, 29(4):475-85.

Narayan, P.K., Narayan, S., and Sharma, S., (2013) An analysis of commodity markets: What gain for investors? Journal of Banking and Finance, 37, 3878-3889.

Nason, J. and Rogers, J. (2002) "Investment and the current account in the short run and the long run" Journal of Money, Credit and Banking, 34. 
Normandin, M. (1999) "Budget deficit persistence and the twin deficits hypothesis" Journal of International Economics, 49, 171-193.

Obstfeld, M. and Rogoff, K. (1996) Foundations of International Macroeconomics, MIT Press, Boston.

Rapach, D.E., and Wohar, M.E., (2006) In-sample vs. out-of-sample tests of stock return predictability in the context of data mining, Journal of Empirical Finance, 13, 231-247.

Rapach, D.E., and Weber, C.E., (2004) Financial variables and the simulated out-ofsample forecastability of U.S. output growth since 1985: An encompassing approach, Economic Inquiry, 42, 717-738.

Ricciutti, R., (2003) Assessing Ricardian Equivalence, Journal of Economic Surveys, 17, 1.

Romer, D. (2012) Advanced Macroeconomics, $4^{\text {th }}$ ed, McGraw Hill, New York.

Sachs, J. (1981) "The Current Account and Macroeconomic Adjustment in the 1970's" Brookings Papers on Economics Activity, 1, 1981, 201-282.

Seater, J. (1993) “Ricardian Equivalence.” Journal of Economic Literature, 31(1): 14290.

Sheffrin, S., \& Woo, W. (1990). Present value tests of an intertemporal model of the current account. Journal of International Economics 29, 237-253.

Stambaugh, R.F., (1999) Predictive regressions, Journal of Financial Economics, 54, $375-421$. 
Taylor, J. (2011), “An Empirical Analysis of the Revival of Fiscal Activism in the 2000s" Journal of Economic Literature, 49, September, 686-702.

Westerlund, J., and Narayan, P.K., (2011) Testing for predictability in heteroskedastic stock returns, Unpublished Manuscript.

Westerlund, J., and Narayan, P.K., (2012) Does the choice of estimator matter when forecasting returns? Journal of Banking and Finance, 36, 2632-2640. 
Table 1: Unit root test results

\begin{tabular}{|c|c|c|c|c|}
\hline & Australia & New Zealand & UK & USA \\
\hline$C A D / Y$ & $\begin{array}{c}-2.942 * * \\
(0.045)\end{array}$ & $\begin{array}{c}-3.149 * * \\
(0.027)\end{array}$ & $\begin{array}{c}-4.209 * * * \\
(0.001)\end{array}$ & $\begin{array}{l}-2.305 \\
(0.173)\end{array}$ \\
\hline$\triangle C A D / Y$ & $\begin{array}{c}-8.560 * * * \\
(0.000)\end{array}$ & $\begin{array}{c}-14.625 * * * \\
(0.000)\end{array}$ & $\begin{array}{c}-9.589 * * * \\
(0.000)\end{array}$ & $\begin{array}{c}-4.520 * * * \\
(0.000)\end{array}$ \\
\hline$G / Y$ & $\begin{array}{l}-2.375 \\
(0.152)\end{array}$ & $\begin{array}{l}-1.070 \\
(0.724)\end{array}$ & $\begin{array}{l}-0.444 \\
(0.896)\end{array}$ & $\begin{array}{l}-1.377 \\
(0.590)\end{array}$ \\
\hline$\Delta G / Y$ & $\begin{array}{c}11.918^{* * * *} \\
(0.000)\end{array}$ & $\begin{array}{c}14.428 * * * \\
(0.000)\end{array}$ & $\begin{array}{c}-7.009 * * * \\
(0.000)\end{array}$ & $\begin{array}{c}-4.235 * * * \\
(0.001)\end{array}$ \\
\hline$I / Y$ & $\begin{array}{l}-1.485 \\
(0.536)\end{array}$ & $\begin{array}{l}-1.420 \\
(0.569)\end{array}$ & $\begin{array}{l}-2.663 * \\
(0.085)\end{array}$ & $\begin{array}{l}-1.616 \\
(0.470)\end{array}$ \\
\hline$\Delta I / Y$ & $\begin{array}{c}-8.838 * * * \\
(0.000)\end{array}$ & $\begin{array}{c}-10.268 * * * \\
(0.000)\end{array}$ & $\begin{array}{c}-8.861 * * * \\
(0.000)\end{array}$ & $\begin{array}{c}-5.675 * * * \\
(0.000)\end{array}$ \\
\hline$C / Y$ & $\begin{array}{l}-3.342 * \\
(0.066)\end{array}$ & $\begin{array}{c}-3.974 * * \\
(0.013)\end{array}$ & $\begin{array}{l}-2.939 \\
(0.116)\end{array}$ & $\begin{array}{l}-2.205 \\
(0.480)\end{array}$ \\
\hline$\Delta C / Y$ & $\begin{array}{c}-6.735 * * * \\
(0.000)\end{array}$ & $\begin{array}{c}-11.559 * * * \\
(0.000)\end{array}$ & $\begin{array}{c}-12.311 * * * \\
(0.000)\end{array}$ & $\begin{array}{c}-12.287 * * * \\
(0.000)\end{array}$ \\
\hline
\end{tabular}

Notes: This table reports the ADF test results. The ADF model includes a time trend and intercept for the level variables and only intercept in the case of the first differenced variables. The optimal lag length, used to control for serial correlation, is selected using the Schwarz Information Criterion. In doing so, the maximum lag length is set to eight. The null hypothesis is that there is a unit root. The test statistics are reported together with the p-values in parenthesis. $*(* *) * * *$ denote statistical significance at the $10 \%, 5 \%$, and $1 \%$ levels, respectively. 
Table 2: Results on endogeneity of predictor variables

\begin{tabular}{|l|c|c|c|c|l|l|}
\hline Countries & \multicolumn{2}{|l|}{ Government Spending } & \multicolumn{2}{c|}{ Investment } & \multicolumn{2}{l|}{ Consumption } \\
\hline & $\gamma$ & t-statistics & $\gamma$ & t-statistics & $\gamma$ & t-statistics \\
\hline Australia & -0.045 & -0.802 & 0.352 & 1.591 & -0.066 & -0.253 \\
\hline NZ & 0.004 & 0.061 & $0.367 * * *$ & 4.722 & 0.007 & 0.072 \\
\hline UK & $0.359^{*}$ & 1.864 & 0.196 & 1.106 & -0.278 & -0.359 \\
\hline USA & $-0.001 *$ & -1.916 & 0.001 & 1.170 & -0.179 & -7.291 \\
\hline
\end{tabular}

Notes: This table reports the test for endogeneity of the predictor variable. The coefficient of $y$ based on Equation (9) is reported together with the t-test statistic which tests the null that $\gamma=0$. * (***) denote statistical significance at the $10 \%$ and $1 \%$ levels, respectively. 
Table 3: Lewellen and Westerlund and Narayan test for predictability

\begin{tabular}{|c|c|c|c|c|}
\hline \multicolumn{5}{|c|}{ Panel A: When Government Spending is the predictor variable } \\
\hline Countries & \multicolumn{2}{|c|}{ Lewellen } & \multicolumn{2}{|c|}{ Narayan and Westerlund } \\
\hline & coefficient & t-statistic & Coefficient & t-statistics \\
\hline Australia & $-0.128 * * *$ & -3.898 & $-0.099 * * *$ & -3.513 \\
\hline New Zealand & -0.009 & -0.168 & 0.053 & 1.482 \\
\hline UK & $0.637 * * *$ & 4.295 & $0.745 * * *$ & 7.898 \\
\hline USA & $-0.003 * * *$ & -3.737 & $-0.002 * * *$ & -2.527 \\
\hline \multicolumn{5}{|c|}{ Panel B: When Investment is the predictor variable } \\
\hline \multirow[t]{2}{*}{ Countries } & \multicolumn{2}{|c|}{ Lewellen } & \multicolumn{2}{|c|}{ Narayan and Westerlund } \\
\hline & coefficient & t-statistic & coefficient & t-statistic \\
\hline Australia & $0.767 * * *$ & 5.979 & $0.800 * * *$ & 7.859 \\
\hline New Zealand & $0.589 * * *$ & 9.347 & $0.525 * * *$ & 9.693 \\
\hline UK & $0.398 * * *$ & 2.914 & $0.292 * * *$ & 3.082 \\
\hline USA & $0.003 * * *$ & 2.486 & $0.004 * * *$ & 4.178 \\
\hline \multicolumn{5}{|c|}{ Panel C: When consumption is the predictor variable } \\
\hline \multirow[t]{2}{*}{ Countries } & \multicolumn{2}{|c|}{ Lewellen } & \multicolumn{2}{|c|}{ Narayan and Westerlund } \\
\hline & coefficient & t-statistic & coefficient & t-statistic \\
\hline Australia & 0.055 & 0.708 & 0.064 & 0.869 \\
\hline New Zealand & -0.084 & -0.374 & -0.084 & -0.351 \\
\hline UK & -0.153 & -1.012 & -0.033 & -0.229 \\
\hline USA & $14.231 *$ & 1.759 & $14.231 *$ & 1.746 \\
\hline
\end{tabular}

Notes: The table reports the results on the null hypothesis of no predictability. Panel A contains results when government spending is the predictor variable, while Panels $\mathrm{B}$ and $\mathrm{C}$ report results when investment and consumption are used as predictors. Results are based on two predictors-the Lewellen adjusted-OLS estimator and the Westerlund and Narayan GLS estimator. * (***) denote statistical significance at the $10 \%$ and $1 \%$ levels, respectively. 
Table 4: Out-of-sample forecasting performance

\begin{tabular}{|c|c|c|c|c|}
\hline & \multicolumn{2}{|l|}{ Investment } & \multirow[b]{2}{*}{ UK } & \multirow[b]{2}{*}{ USA } \\
\hline & Australia & $\mathrm{NZ}$ & & \\
\hline RMSFE & $\begin{array}{c}0.94871 * * * \\
(0.0100)\end{array}$ & $\begin{array}{c}0.7828 * * * \\
(0.0000)\end{array}$ & $\begin{array}{c}1.1467 \\
(1.0000)\end{array}$ & $\begin{array}{l}0.9871 * \\
(0.1000)\end{array}$ \\
\hline MSE-F & $\begin{array}{c}4.7749 * * * \\
(0.0100)\end{array}$ & $\begin{array}{c}27.159 * * * \\
(0.0000)\end{array}$ & $\begin{array}{l}-10.297 \\
(1.0000)\end{array}$ & $\begin{array}{l}1.1359 * \\
(0.1000)\end{array}$ \\
\hline \multirow[t]{3}{*}{ ENC-new } & $\begin{array}{c}5.9642 * * * \\
(0.0000)\end{array}$ & $\begin{array}{c}18.310 * * * \\
(0.0000)\end{array}$ & $\begin{array}{l}-1.5044 \\
(0.9800)\end{array}$ & $\begin{array}{c}13.376 * * * \\
(0.0000)\end{array}$ \\
\hline & \multicolumn{2}{|l|}{ Govt spending } & & \\
\hline & Australia & $\mathrm{NZ}$ & UK & USA \\
\hline RMSFE & $\begin{array}{c}0.91578 * * * \\
(0.0000)\end{array}$ & $\begin{array}{c}1.0233 \\
(0.1300)\end{array}$ & $\begin{array}{c}0.9432 * * * \\
(0.0100)\end{array}$ & $\begin{array}{c}1.0747 \\
(1.0000) \\
\end{array}$ \\
\hline MSE-F & $\begin{array}{c}8.2726 * * * \\
(0.0000)\end{array}$ & $\begin{array}{l}-1.9383 \\
(0.1300) \\
\end{array}$ & $\begin{array}{c}5.3401 * * * \\
(0.0100) \\
\end{array}$ & $\begin{array}{c}-5.7714 \\
(1.0000) \\
\end{array}$ \\
\hline \multirow[t]{3}{*}{ ENC-new } & $\begin{array}{c}5.9642 * * * \\
(0.0000)\end{array}$ & $\begin{array}{l}-0.6891 \\
(0.5600)\end{array}$ & $\begin{array}{c}9.8058 * * * \\
(0.0100)\end{array}$ & $\begin{array}{c}-1.8408 \\
(1.0000)\end{array}$ \\
\hline & \multicolumn{2}{|l|}{ Consumption } & & \\
\hline & Australia & $\mathrm{NZ}$ & $\mathrm{UK}$ & USA \\
\hline RMSFE & $\begin{array}{l}1.0577 \\
(1.000) \\
\end{array}$ & $\begin{array}{l}1.0062 \\
(0.380) \\
\end{array}$ & $\begin{array}{l}1.0228 \\
(0.810) \\
\end{array}$ & $\begin{array}{c}0.9871 * \\
(0.060) \\
\end{array}$ \\
\hline MSE-F & $\begin{array}{l}-4.5657 \\
(1.000) \\
\end{array}$ & $\begin{array}{l}-0.5291 \\
(0.380) \\
\end{array}$ & $\begin{array}{l}-1.8957 \\
(0.810) \\
\end{array}$ & $\begin{array}{l}1.1319 * \\
(0.060)\end{array}$ \\
\hline ENC-new & $\begin{array}{l}3.4351 * * \\
(0.0200)\end{array}$ & $\begin{array}{c}-0.2121 \\
(0.540) \\
\end{array}$ & $\begin{array}{c}-0.7954 \\
(0.910)\end{array}$ & $\begin{array}{l}0.5780 \\
(0.200)\end{array}$ \\
\hline
\end{tabular}

Notes: This table reports the out-of-sample performance of the predictive regression model vis-à-vis a constant model of CAD forecasts. We report three statistics, namely, RMSFE, MSE-F, and the ENC-NEW. $* *(* * *)$ denote statistical significance at the $5 \%$ and $1 \%$ levels, respectively. 
Table 5: Predictability test results (1990Q1 to 2011Q4)

\begin{tabular}{|l|c|c|}
\hline \multicolumn{2}{|c|}{ Panel A: In-sample; when government spending and consumption are predictors } \\
\hline Country & Government spending & Consumption \\
\hline USA & $-0.8033^{* * *}$ & $0.9395^{* * *}$ \\
& $(-6.5839)$ & $(13.6174)$ \\
\hline UK & $0.2025^{* * *}$ & -0.0038 \\
& $(3.0054)$ & $(-0.0365)$ \\
\hline Australia & $-1.3006^{* * *}$ & 0.1235 \\
& $(-4.2926)$ & $(1.6960)$ \\
\hline New Zealand & -0.2434 & -0.0884 \\
& $(-1.1077)$ & $(-0.3914)$ \\
\hline
\end{tabular}

Panel B: In-sample; when government spending and investment are predictors

\begin{tabular}{|c|c|c|}
\hline \multirow{2}{*}{$\frac{\text { Country }}{\text { USA }}$} & Government spending & Investment \\
\hline & $\begin{array}{c}-0.8632 * * * \\
(2.8544)\end{array}$ & $\begin{array}{c}0.9929 * * * \\
(5.2903)\end{array}$ \\
\hline UK & $\begin{array}{c}0.4131 * * \\
(5.8705)\end{array}$ & $\begin{array}{c}0.4036 * * * \\
(5.3233)\end{array}$ \\
\hline Australia & $\begin{array}{c}-0.7255 * * \\
(-2.1996)\end{array}$ & $\begin{array}{c}0.2245 * * * \\
(2.8704)\end{array}$ \\
\hline New Zealand & $\begin{array}{c}0.1787 \\
(0.9471)\end{array}$ & $\begin{array}{c}0.7878 * * * \\
(6.6787)\end{array}$ \\
\hline \multicolumn{3}{|c|}{ Panel C: In-sample; when consumption and investment are predictors } \\
\hline Country & Consumption & Investment \\
\hline USA & $\begin{array}{c}0.8982 * * * \\
(18.5047) \\
\end{array}$ & $\begin{array}{c}0.6757 * * * \\
(12.6334)\end{array}$ \\
\hline UK & $\begin{array}{c}0.1269 \\
(1.0891)\end{array}$ & $\begin{array}{c}0.1905 * * \\
(2.3381)\end{array}$ \\
\hline Australia & $\begin{array}{c}0.7499 * * * \\
(9.7322)\end{array}$ & $\begin{array}{c}0.8826 * * * \\
(11.6091)\end{array}$ \\
\hline New Zealand & $\begin{array}{c}0.3791 \\
(1.9828)\end{array}$ & $\begin{array}{c}0.8295 * * * \\
(7.1345)\end{array}$ \\
\hline
\end{tabular}

Panel D: Out-of-sample relative Theil $U$ statistic for the multivariate predictive regression model

\begin{tabular}{|l|c|c|c|}
\hline & $\begin{array}{c}\text { Govt. spending and } \\
\text { consumption } \\
\text { predictors }\end{array}$ & $\begin{array}{c}\text { Govt. spending and } \\
\text { investment } \\
\text { predictors }\end{array}$ & $\begin{array}{c}\text { Investment and } \\
\text { consumption } \\
\text { predictors }\end{array}$ \\
\hline USA & 0.4347 & 1.0241 & 0.2709 \\
\hline UK & 0.8254 & 0.8733 & 1.4176 \\
\hline Australia & 0.9194 & 0.9405 & 0.6895 \\
\hline
\end{tabular}




\begin{tabular}{|l|c|c|c|}
\hline New Zealand & 1.0885 & 0.7808 & 0.7502 \\
\hline
\end{tabular}

Notes: $* *(* * *)$ denote statistical significance at the $5 \%$ and $1 \%$ levels, respectively. 
Table 6: Predictability test results over the pre-crisis period (1990Q1 to 2006Q4)

\begin{tabular}{|c|c|c|}
\hline \multicolumn{3}{|c|}{ Panel A: When government spending and consumption are predictors } \\
\hline Country & Government spending & Consumption \\
\hline USA & $\begin{array}{l}-0.3453^{* *} \\
(2.5004)\end{array}$ & $\begin{array}{l}1.1771^{* * * *} \\
(14.5513)\end{array}$ \\
\hline UK & $\begin{array}{c}0.3782 * * * \\
(3.5974)\end{array}$ & $\begin{array}{c}0.0696 \\
(0.6087)\end{array}$ \\
\hline Australia & $\begin{array}{l}-0.6856 \\
(-1.8526)\end{array}$ & $\begin{array}{l}-0.3296 \\
(-1.7779)\end{array}$ \\
\hline New Zealand & $\begin{array}{c}-0.1430 \\
(-0.4339) \\
\end{array}$ & $\begin{array}{c}-0.0722 \\
(-0.3068) \\
\end{array}$ \\
\hline \multicolumn{3}{|c|}{ Panel B: When government spending and investment are predictors } \\
\hline Country & Government spending & Investment \\
\hline USA & $\begin{array}{c}0.8886 * * * * \\
(3.2638)\end{array}$ & $\begin{array}{c}1.7727 * * * \\
(8.7221)\end{array}$ \\
\hline UK & $\begin{array}{c}0.4575 * * * \\
(5.2263)\end{array}$ & $\begin{array}{c}0.5049 * * * \\
(5.3849)\end{array}$ \\
\hline Australia & $\begin{array}{c}0.5235 \\
(1.8626)\end{array}$ & $\begin{array}{c}0.7107^{* * * *} \\
(8.5014)\end{array}$ \\
\hline New Zealand & $\begin{array}{c}0.7561 * * * \\
(2.9492)\end{array}$ & $\begin{array}{c}0.7833 * * * \\
(7.0863)\end{array}$ \\
\hline \multicolumn{3}{|c|}{ Panel C: When consumption and investment are predictors } \\
\hline Country & Consumption & Investment \\
\hline USA & $\begin{array}{c}0.9574^{* * * *} \\
(12.2898)\end{array}$ & $\begin{array}{c}0.6184^{* * * *} \\
(6.2290)\end{array}$ \\
\hline UK & $\begin{array}{c}0.1465 \\
(1.2527)\end{array}$ & $\begin{array}{c}0.4578 * * * \\
(3.9773)\end{array}$ \\
\hline Australia & $\begin{array}{c}0.4247 * * * \\
(2.9145)\end{array}$ & $\begin{array}{c}0.7885 * * * \\
(9.1113) \\
\end{array}$ \\
\hline New Zealand & $\begin{array}{l}0.3215 \\
(1.8257)\end{array}$ & $\begin{array}{c}0.6886 * * * \\
(6.4763)\end{array}$ \\
\hline
\end{tabular}

Notes: $* *(* * *)$ denote statistical significance at the $5 \%$ and $1 \%$ levels, respectively. 
Figure 1 - Average Current Account Deficits 1990-2011 (\% of GDP)

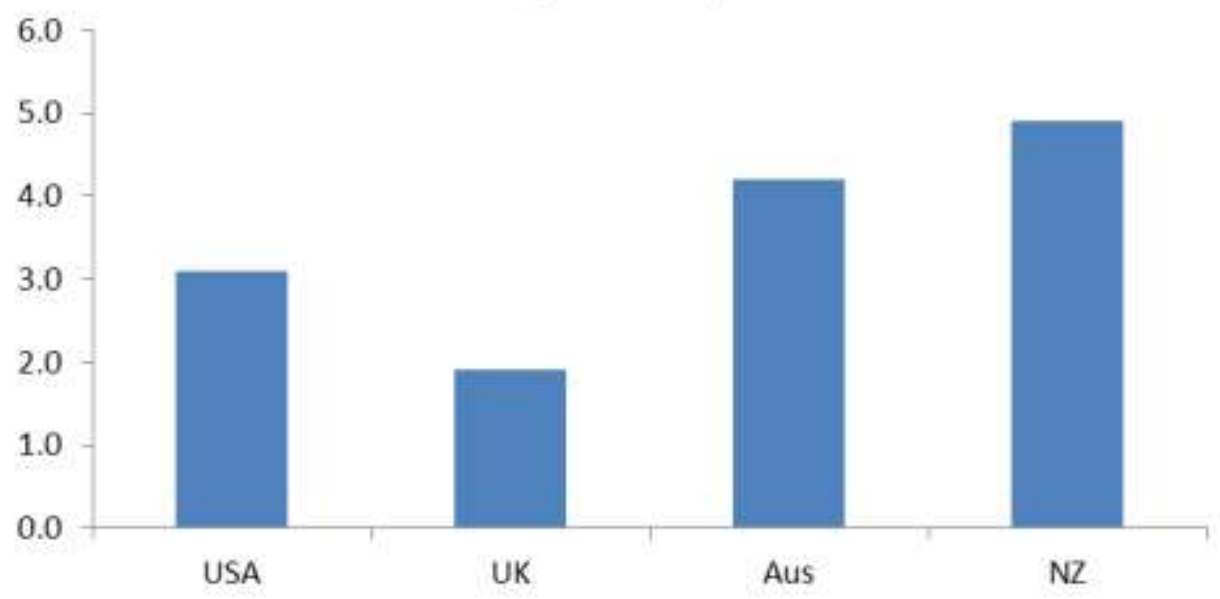

Source: OECD Database 


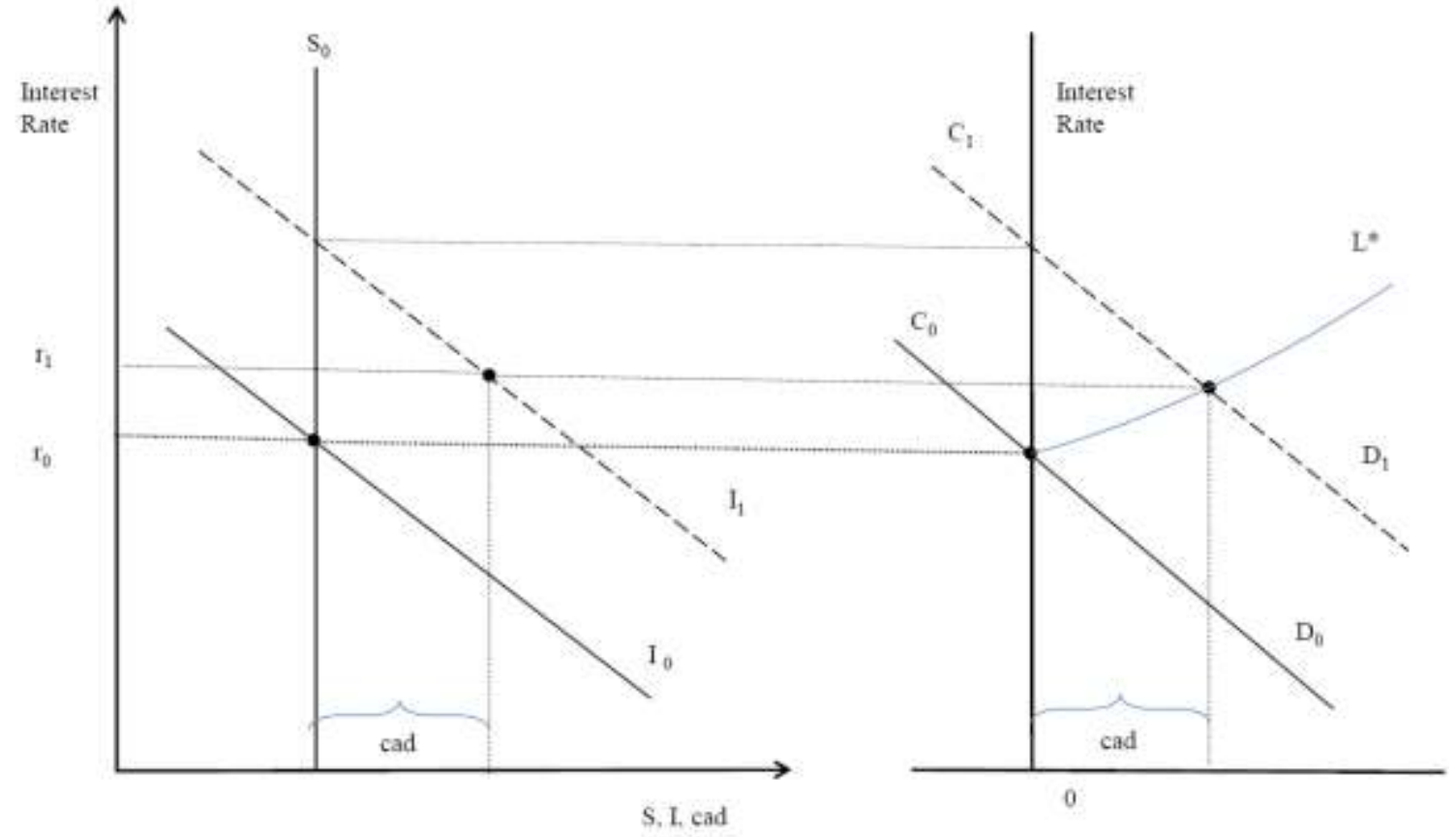

Figure 2 - Investment, the Current Account Deficit and Foreign Borrowing 


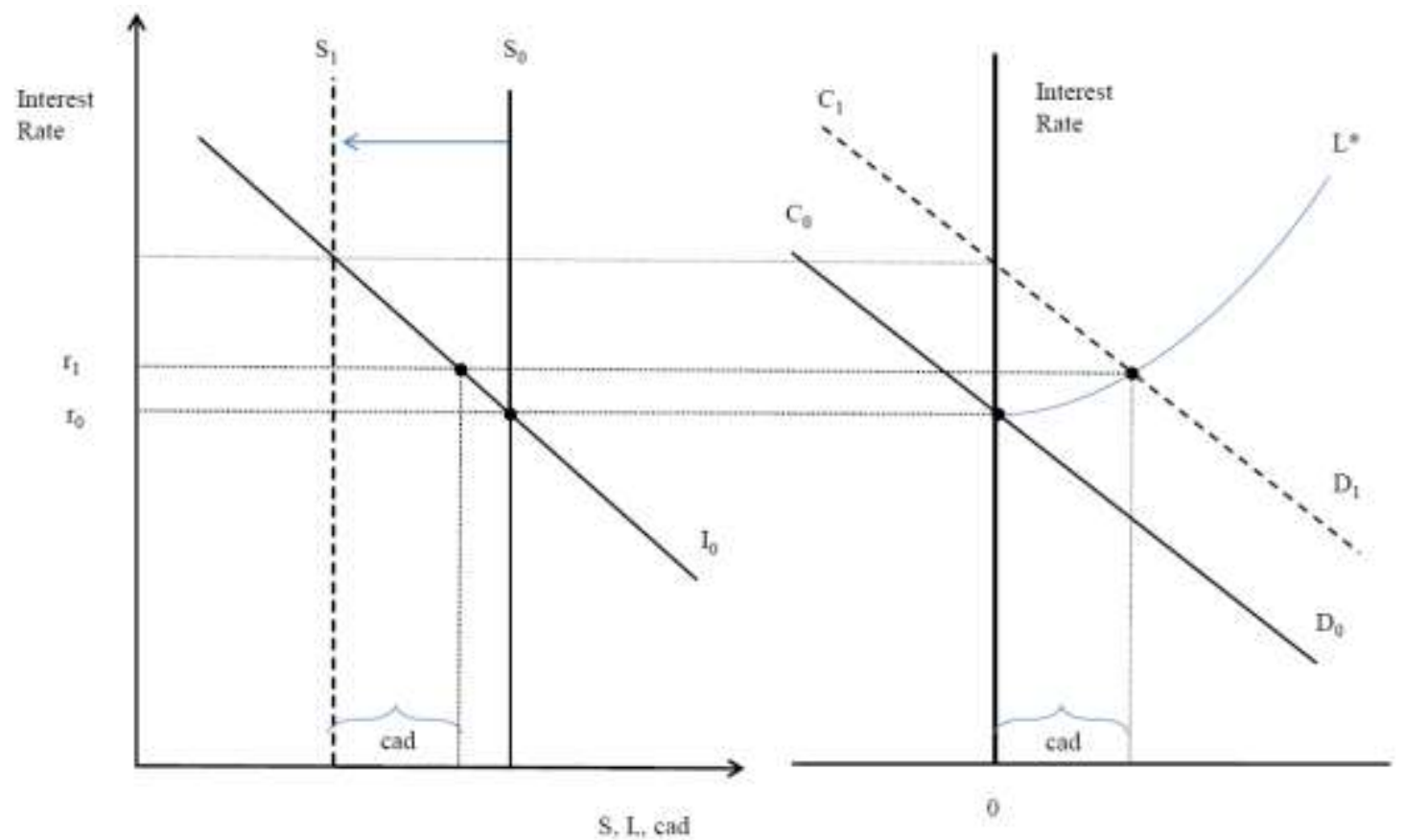

Figure 3 - Household Consumption, Government Spending, and Foreign Borrowing 
Figure 4: Unconditional time-varying correlation between CAD and its predictors Panel A: USA

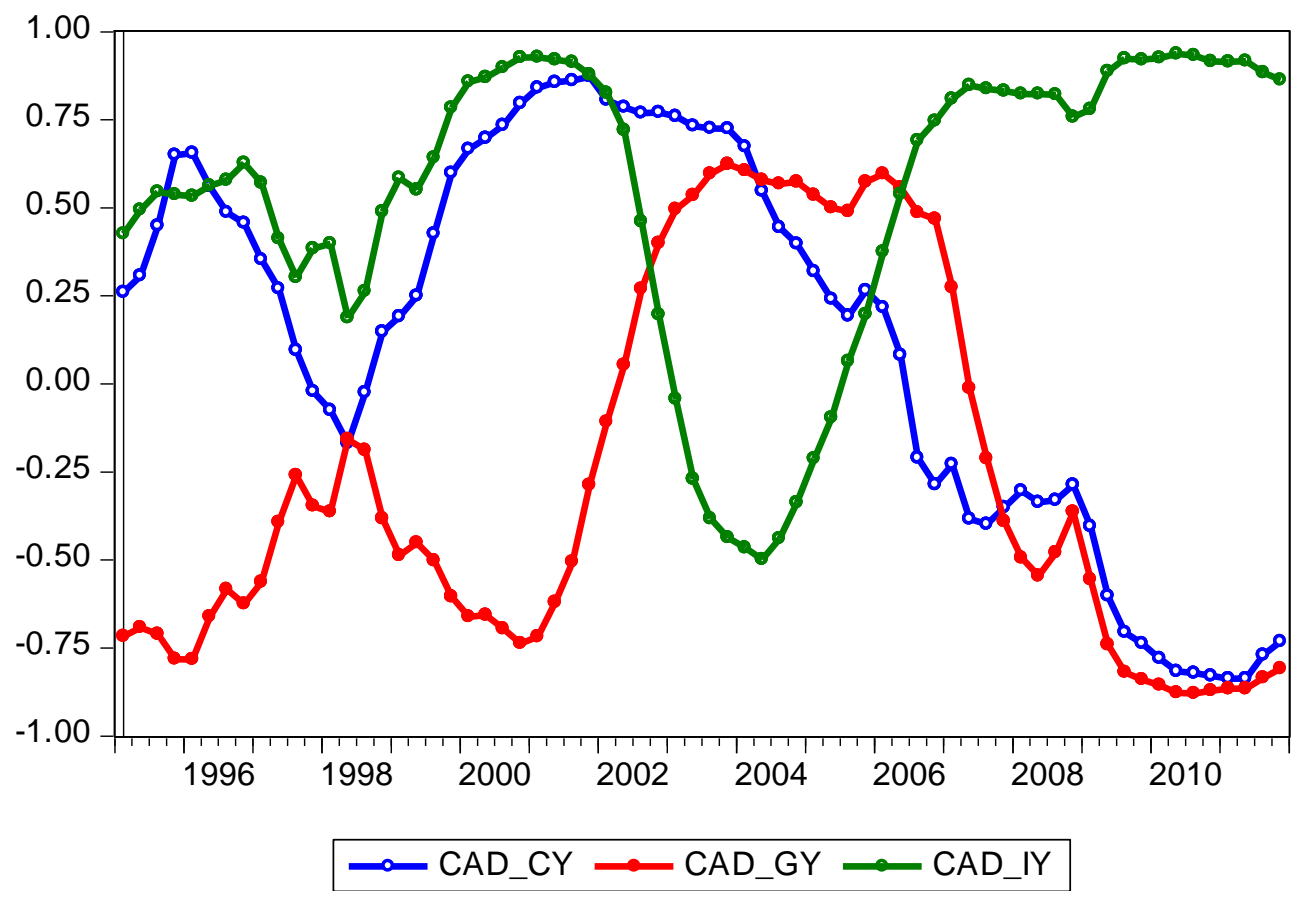

Panel B: UK

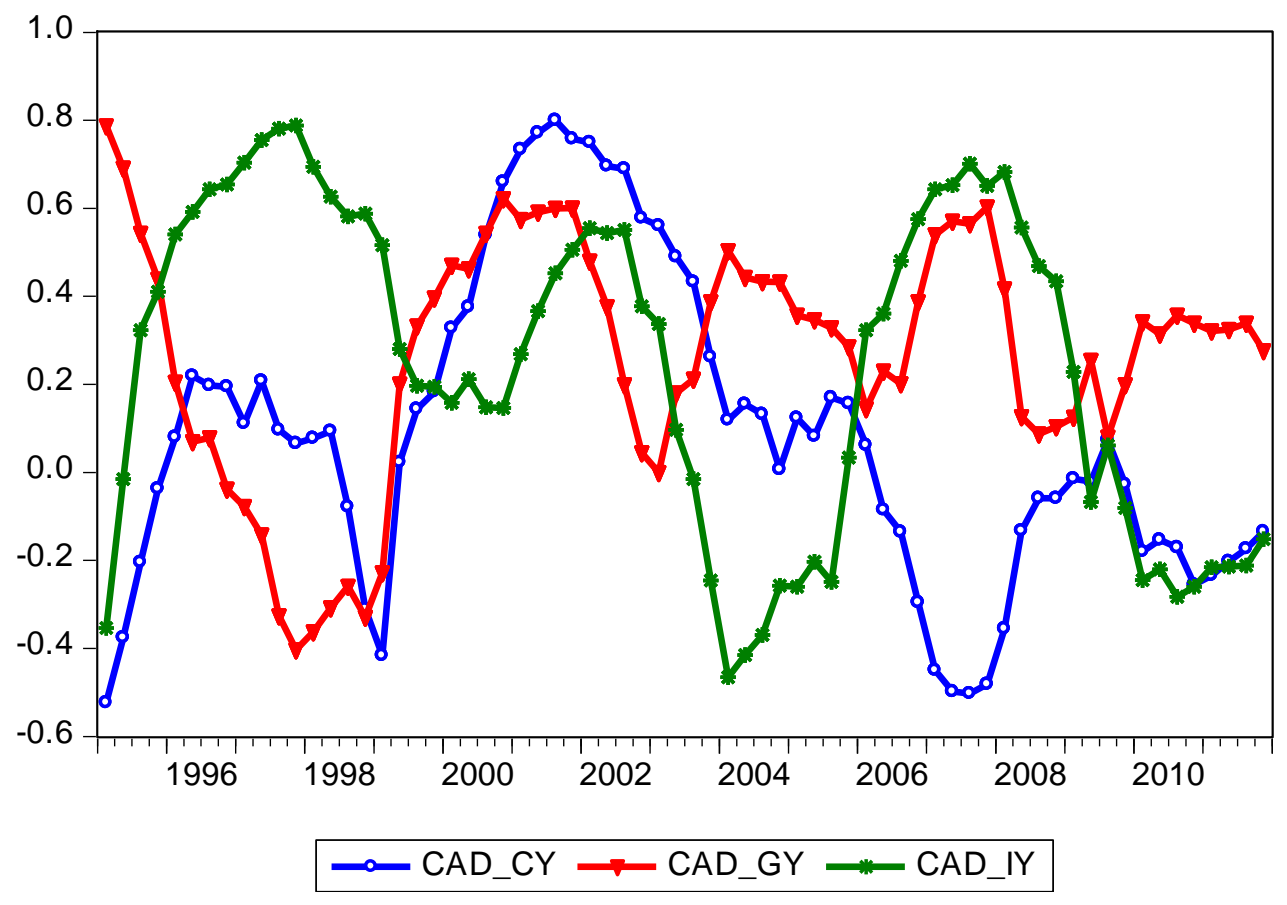


Panel C: Australia

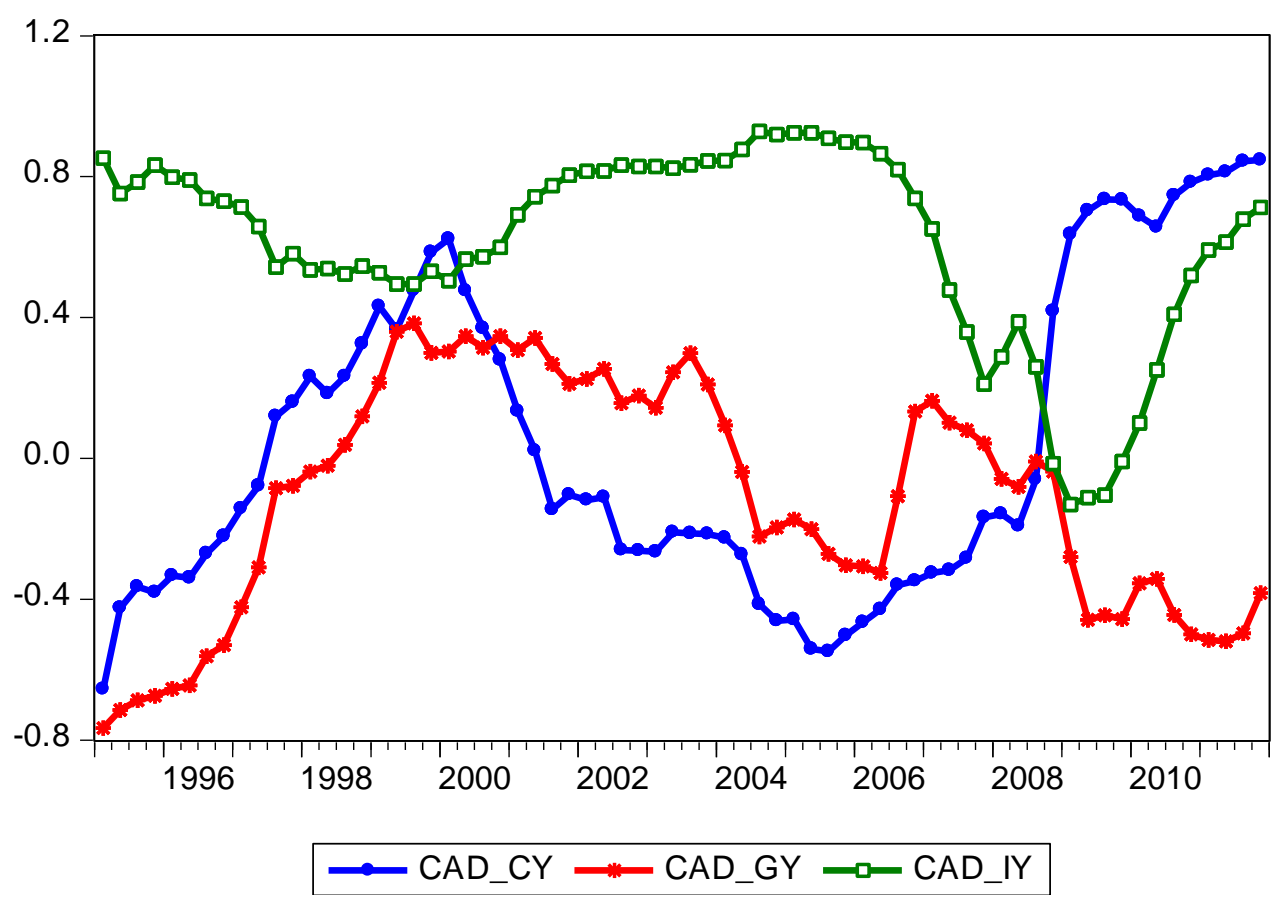

Panel D: New Zealand

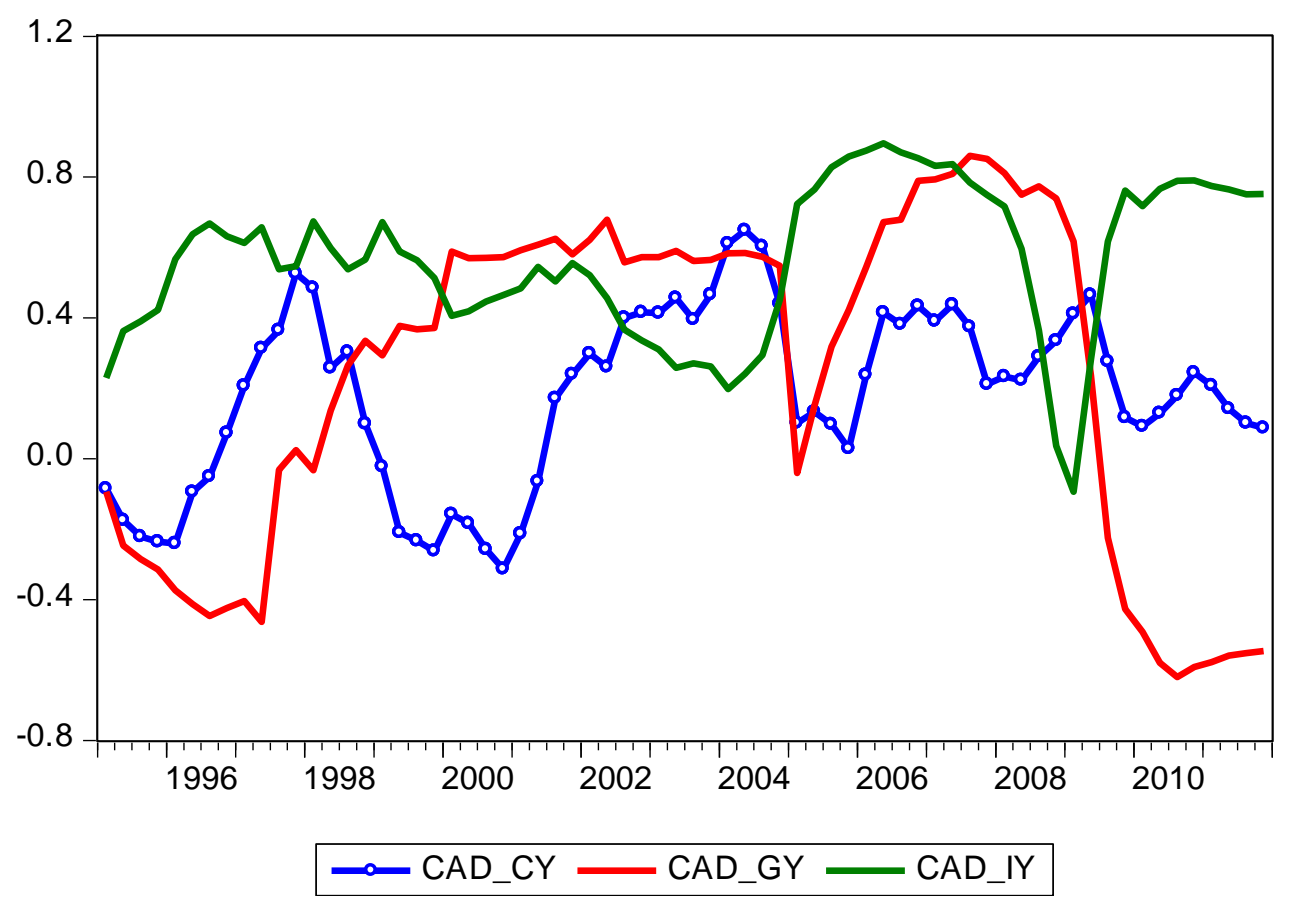

